\title{
Analysis of Competitor Intelligence as Product Strategy Business Development
}

\author{
Syukri Yusuf Nasution \\ Center for Innovation \\ Indonesian Institute of Sciences (LIPI) \\ Bogor, Indonesia \\ syukri.pusinov.lipi@gmail.com
}

\begin{abstract}
Competitor Intelligence is a form of intelligence business where collection of the data and information is Analysed and transformed for use in strategic planning and problem solving. Competitor Intelligence is one of the strategies that used as business development products. In this research Competitor Intelligence uses to enhance competitiveness of Product X LIPI so that the product more acceptable in the market. This study uses quantitative and qualitative methods by collecting data on similar products to determine the strengths and weakness of each product. The analysis carried out by determining 7 criteria success factors which then conducted an in-depth analysis to generate new added value. From the results of the Competitor Intelligence analysis showed that from 7 criteria success factors defined, there are $\mathbf{2}$ criteria success factors that should be added to product $X$ LIPI in order to improve product competitiveness in the market.
\end{abstract}

Keywords- Competitor Intelligence, business strategy development, success factors, added value, competitiveness

\section{INTRODUCTION}

In business development process is required a good business strategy so that the new product which will be launched can be accepted in the market. The strategic business can be a powerful marketing strategy. One of the marketing strategies that often to be used is Competitor Intelligence. The Competitor Intelligence could play an important role in improving product performance by identifying new opportunities, highlighting potential threats, revealing new business insights and enhancing decision making processes among many other benefits [1]. Xia and Gong cited a survey conducted by Thomson in 2004 suggesting that the major benefits of Competitor Intelligence are generating faster and more accurate reporting $(81 \%)$, improved business decision making (78\%), improved customer service (56\%) and increasing company revenue (49\%) [1]. Competitor Intelligence can be made after market segmentation determined. In same segmentation, it is possible to find similar products. With Competitor Intelligence analysis can provide an overview about the position of the product with the other products.

Competitor intelligence in business is inspired by the theory of war Sun Tzu (500 BC), where Sun Tzu suggested several things that can be used in the process of business competition. First is know the enemy and know yourself, in a hundred battles you will never be in peril; the second is when you are ignorant of the enemy but know yourself, your chances of winning or losing are equal; and the third theory if ignorant both of your enemy and of yourself, you are certain in every battle to be in peril [2].

From that theory, if applied to business competition, only company which knows its own abilities and knows the competitors will have a big chance to win in competition. Company with lack information about market and competitors usually will not survive in competition. One way to find out the competitors with performs intelligence. Philip Kotler in his definitive Marketing Management gave four possible definitions of competitors. First competitor is a company who offering a similar product and services to the same customers at similar prices. The second is a company who making the same product or class of products. The third is a company who making products that supply the same service. And the fourth is a company who competing for the same customer's available money [3].

The process of doing reconnaissance a competitor so is manifold, starting from the easiest things that become ghost shopper at specific events, searching the data directly to consumers, manufacturers, suppliers, and others using questionnaires or interviews, or it can be collecting valid data from relevant research agencies in accordance with what they want to know from their competitors which can be used as essential information to make a key decision in order to sale the product.

\section{THE IMPORTANCE OF COMPETITORS INTELLIGENCE}

Gathering competitive intelligence is important for businesses due to several reasons [4], [5], [6]:

- Enhancing the enterprise's competitiveness,

- predicting, with a high level of trust, the business environment's evolutions, supply chain activities, competitors' actions, customers' requirements and even influences generated by political change,

- providing better support for the strategic decisionmaking process,

- revealing opportunities and threats by surveying weak signals and early warnings,

- processing and combining data and information to 
- produce knowledge and insights on competitors,

- satisfying the information needs of decision-making and problem solving, and decreasing reaction time,

- devising marketing strategies.

From those above, competitor intelligence is not just about collecting information, but it is about analysing the information, filtering it, learning what is useful and what is not and then using it to business profit. Consider the findings of a McKinsey study that asked executives how their firms responded either to a significant price change by a competitor or to a significant innovation by a competitor: A majority of executives in both groups [across regions and industries] say their companies found out about the [significant] competitive move too late to respond before it hit the market [7].

\section{RESEARCH METHOD}

This study uses quantitative and qualitative methods with descriptive analysis. This research uses primary and secondary data. Primary data obtained by observation and interview, while secondary data obtained from books, online information and other indirect references. In conducting this analysis, the Critical Success Factors are defined. The critical success factors used to describe the criteria that will be compared with others products. Besides that, this research also conducted sampling of the competitors' products with similar criteria with product X LIPI. In depth analyses carry out to get the best final key decision in order to determine the best strategy marketing for product. Figure below shown the mechanism to determine the strategy of Competitor Intelligence Analysis [8]:

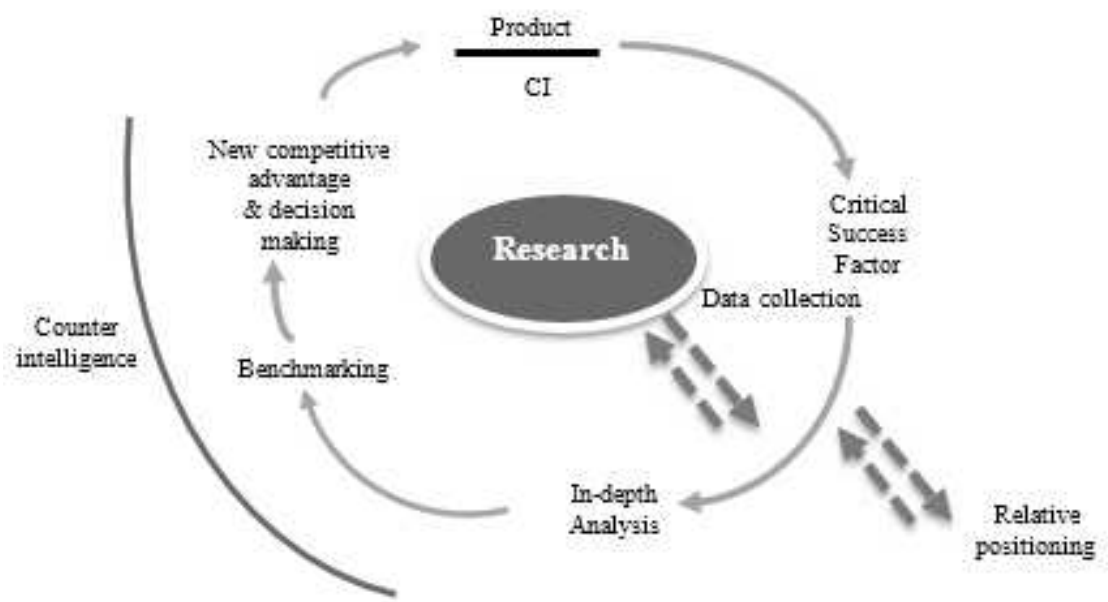

Fig. 1. Procedures to the determination Competitor Intelligence of product

\section{DISCUSSION}

\section{Collecting data and CSF' Analysis}

From Fig. 1. the first step to do CI analysis should determine the Critical Success Factors (CSF's). Critical Success Factors (CSF's) are the critical factors or activities required for ensuring the success the business. Critical success factors were introduced by John F. Rockart and the MIT Sloan School of Management in 1979 as a way to help senior executives define their information needs for the purpose of managing their organizations [9]. Rockart introduced a twophased, interview-based method that began with a discussion and the underlying CSFs, followed by the development of CSF measures. Caralli offers a five-step method [10]:

- define scope

- collect data

- analyses data

- derive CSF's

- analyses CSF's

For this analysis, there are 7 critical success factors determined:
1) features (CSF1)

2) material (CSF2)

3) price and payment methods (CSF3)

4) security methods (CSF4)

5) warning indicators (CSF5)

6) functions (CSF6)

7) product value (CSF7)

After determining the critical success factor, the next step is describing the success factor based on data collection so that the relative positioning for each factor defined. There are some requirements to describe success factors [8]:

- descriptions should be measurable,

- descriptions may not provide ambiguous meaning,

- descriptions using gradation level (range),

- descriptions easy to understands,

- descriptions should be objective.

CSF collected from primary and secondary data. Research for primary data should be take 3 steps as shown in following figure below [8]: 


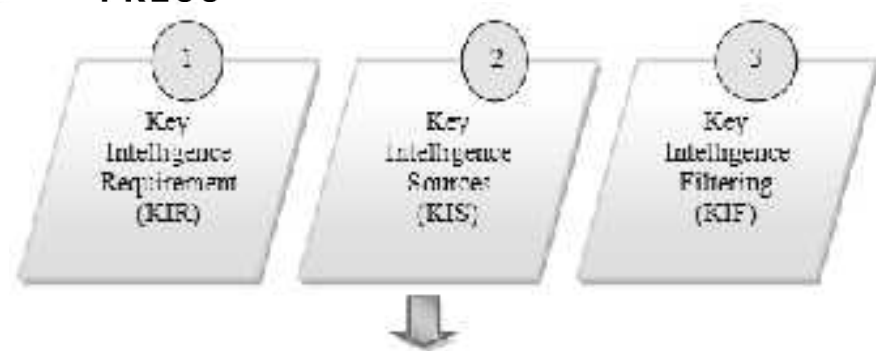

Tho osst result us: primary ista mose than $805 \%$ and vcrificd. Data collection cuscucter to stakeliolders. costumers, supphess, and mother scurces to give the spezific iriormation $s 0$ that san be erakrod wcil

Fig. 2. Procedures to collect data until filtering the data

Costumer analysis needed to check out what the most important needed in the market. Customer oriented analysis techniques always performed by companies to analysis the demand of market. Customer value can usually be achieved only when product quality, service quality, and value-based prices are in harmony and exceed customer expectations. This is illustrated in Fig. 3. below [11]:

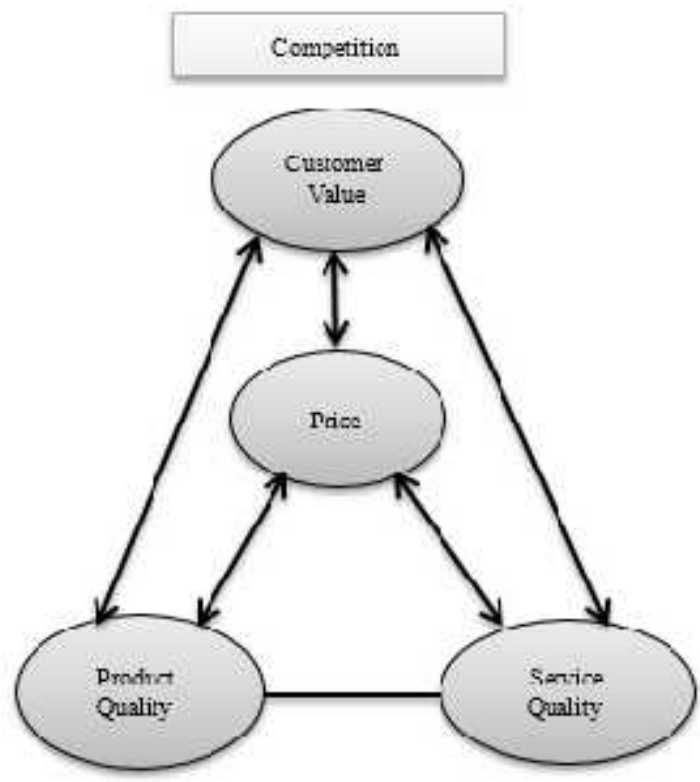

Fig. 3. Collecting data based on Customer oriented analysis

Relative Positioning and In-depth Analysis

The easiest way to describe CSF is with making grade for each relative positioning. Numeric used to grading the lower and the highest value. The value started from 1 to 5 with grade 5 is the best level and grade 1 is the worst. Table below shown the descriptions for each critical success factor:

TABLE I. RELATIVE POSITIONING FOR CSF1

\begin{tabular}{|l|l|l|}
\hline No & \multicolumn{1}{|c|}{ Criteria } & Grade \\
\hline 1 & $\begin{array}{l}\text { Attractive, Light (weight } \leq 100 \text { gram), Small size ( size } \\
\leq 10 \mathrm{~cm} \text { ), Small power supply(energy consumption } \leq 1 \\
\text { Watt) }\end{array}$ & 5 \\
\hline 2 & $\begin{array}{l}\text { Attractive, Light (weight } \leq 100 \text { gram), Small size (size } \\
\leq 10 \mathrm{~cm}), \text { Medium power supply energy consumption } \\
\text { between 1-3 Watt) }\end{array}$ & 4 \\
\hline
\end{tabular}

\begin{tabular}{|l|l|l|}
\hline \multicolumn{2}{|l|}{ (“Table I, cont.) } \\
\hline 3 & $\begin{array}{l}\text { Attractive, Light (weight } \leq 100 \text { gram), Big size ( size > } \\
10 \mathrm{~cm} \text { ), High power supply (energy consumption > 3 } \\
\text { Watt) }\end{array}$ & 3 \\
\hline 4 & $\begin{array}{l}\text { Attractive, Heavy (weight > } 100 \text { gram), Big size (size > } \\
10 \mathrm{~cm}), \text { High power supply (energy consumption > 3 } \\
\text { Watt) }\end{array}$ & 2 \\
\hline 5 & $\begin{array}{l}\text { Not Attractive, Heavy (weight > 100 gram), Big size } \\
(\text { size }>10 \mathrm{~cm}), \text { High power supply (energy consumption } \\
>3 \text { Watt) }\end{array}$ & 1 \\
\hline
\end{tabular}

${ }^{\text {a. }}$ Source: primary and secondary data

TABLE II. RELATIVE POSITIONING FOR CSF2

\begin{tabular}{|l|l|l|}
\hline No & \multicolumn{1}{|c|}{ Criteria } & Grade \\
\hline 1 & $\begin{array}{l}\text { Supply chain available, cost of goods sold } \leq \text { Rp50.000, } \\
\text { Promote Domestic Local Content (level of domestic } \\
\text { content } \geq 30 \%) \text {, Promote nanotechnology }\end{array}$ & 5 \\
\hline 2 & $\begin{array}{l}\text { Suply chain available, Cost of goods sold } \leq \text { Rp50.000, } \\
\text { Promote Domestic Local Content ((level of domestic } \\
\text { content } \geq 30 \%), \text { not promote nanotechnology }\end{array}$ & 4 \\
\hline 3 & $\begin{array}{l}\text { Supply chain available, Cost of goods sold } \leq \text { Rp50.000, } \\
\text { not promote Domestic Local Content (level of domestic } \\
\text { content <30\%), not promote nanotechnology }\end{array}$ & 3 \\
\hline 5 & $\begin{array}{l}\text { Supply chain available, cost of goods sold > Rp50.000, } \\
\text { not promote Domestic Local Content (level of domestic } \\
\text { content <30\%), not promote nanotechnology }\end{array}$ & 2 \\
\hline 5 & $\begin{array}{l}\text { Supply chain not available, cost of goods sold > } \\
\text { Rp50.000, Not promote Domestic Local Content (level } \\
\text { of domestic content < 30\%), not promote } \\
\text { nanotechnology }\end{array}$ & 1 \\
\hline
\end{tabular}

b. Source: primary and secondary data

In TABLE II. DCL calculation based on regulation Ministry of Industry of Republic Indonesia [12]. DCL is one strategy to improve the competitiveness of domestic industry. Industrial policies are designed to help support domestic industry to promote economic growth and employment [13].

TABLE III. RELATIVE POSITIONING FOR CSF3

\begin{tabular}{|c|c|c|}
\hline No & Criteria & Grade \\
\hline 1 & $\begin{array}{l}\text { Cheaper (Price } \leq \text { Rp150.000), Debit/Credit Available, } \\
\text { Instalment Payment available, Have a promo }\end{array}$ & 5 \\
\hline 2 & $\begin{array}{l}\text { Cheaper (Price } \leq \text { Rp150.000), Debit/Credit Available, } \\
\text { Instalment Payment available, No promo }\end{array}$ & 4 \\
\hline 3 & $\begin{array}{l}\text { Expensive (Price > Rp150.000), Debit/Credit Available, } \\
\text { Instalment Payment not available, No promo }\end{array}$ & 3 \\
\hline 4 & $\begin{array}{l}\text { Expensive (Price > Rp150.000), Debit/Credit Available, } \\
\text { Instalment Payment available, Have a promo }\end{array}$ & 2 \\
\hline 5 & $\begin{array}{l}\text { Expensive (Price }>\text { Rp150.000), Debit/Credit not } \\
\text { available (CASH), Instalment Payment not available, } \\
\text { No promo }\end{array}$ & 1 \\
\hline
\end{tabular}

c. Source: primary and secondary data

TABLE IV. RELATIVE POSITIONING FOR CSF4

\begin{tabular}{|l|l|l|}
\hline No & \multicolumn{1}{|c|}{ Criteria } & Grade \\
\hline 1 & Use Sensor, Electric type, High sensitivity, Reusable & 5 \\
\hline 2 & $\begin{array}{l}\text { Use Sensor, Electric type, High sensitivity, Non } \\
\text { Reusable (disposable) }\end{array}$ & 4 \\
\hline 3 & $\begin{array}{l}\text { Use Sensor, Electric type, Low sensitivity, Reusable } \\
\text { Use Sensor, Non Electric type (Mechanic), Low } \\
\text { sensitivity, Non Reusable (disposable) }\end{array}$ & 2 \\
\hline 5 & $\begin{array}{l}\text { Non Sensor (Use actuator), Non Electric type } \\
\text { (Mechanic), Low sensitivity, Non Reusable (disposable) }\end{array}$ & 1 \\
\hline
\end{tabular}

d. Source: primary and secondary data 
From TABLE IV. product X LIPI has strength on the build technology sensor and methods to make the sensor have a high sensitivity. Good sensitivity is one of the most important things that should be owned by similar products.

TABLE V. RELATIVE POSITIONING FOR CSF5

\begin{tabular}{|l|l|l|}
\hline No & \multicolumn{1}{|c|}{ Criteria } & Grade \\
\hline 1 & $\begin{array}{l}\text { Have 3 indicators Lamp, Active Speaker, High tone } \\
\text { volume, Alarm and visual indicators, seven segment } \\
\text { display }\end{array}$ & 5 \\
\hline 2 & $\begin{array}{l}\text { Have 2 indicators Lamp, Active Speaker, High tone } \\
\text { volume, Alarm indicators, Non seven segment display }\end{array}$ & 4 \\
\hline 3 & $\begin{array}{l}\text { Have 2 indicators Lamp, Active Speaker, Low tone } \\
\text { volume, Alarm indicators, Non seven segment display }\end{array}$ & 3 \\
\hline 4 & $\begin{array}{l}\text { Have 3 indicators Lamp, Non Speaker Active, No } \\
\text { Sound, Visual Indicators, Seven segment display }\end{array}$ & 2 \\
\hline 5 & $\begin{array}{l}\text { Have 1 indicators Lamp, Non Speaker Active, No } \\
\text { Sound, Visual Indicators, Non seven segment display }\end{array}$ & 1 \\
\hline
\end{tabular}

e. Source: primary and secondary data

TABLE VI. RELATIVE POSITIONING FOR CSF6

\begin{tabular}{|l|l|l|}
\hline No & \multicolumn{1}{|c|}{ Criteria } & Grade \\
\hline 1 & able to identify until 5 types item & 5 \\
\hline 2 & able to identify until 4 types item & 4 \\
\hline 3 & able to identify until 3 types item & 3 \\
\hline 4 & able to identify until 2 types item & 2 \\
\hline 5 & Just able to identify 1 type item & 1 \\
\hline
\end{tabular}

Critical Success Factor's shown in TABLE VI. closely related to Critical Success factor in Table IV. Functions in CSF
6 are the most criteria needed by consumers. Almost consumers needed product with grade from 3 to 5 . Thereafter the price is the second, the lower price more became desired by consumers than the expensive one.

TABLE VII. RELATIVE POSITIONING FOR CSF7

\begin{tabular}{|l|l|l|}
\hline No & \multicolumn{1}{|c|}{ Criteria } & Grade \\
\hline 1 & $\begin{array}{l}\text { Lifetime } \geq 1 \text { year, No service, Chargeable, Easy to use, } \\
\text { Clear Indicators }\end{array}$ & 5 \\
\hline 3 & $\begin{array}{l}\text { Lifetime } \geq 1 \text { year, No service, Chargeable, Easy to use, } \\
\text { indicators are not clear }\end{array}$ & $\begin{array}{l}\text { Lifetime } \geq 1 \text { year, No service, Chargeable, Difficult to } \\
\text { use, indicators are not clear }\end{array}$ \\
\hline 4 & $\begin{array}{l}\text { Lifetime } \geq 1 \text { year, No service, Non Chargeable, } \\
\text { Difficult to use, indicators are not clear }\end{array}$ & 2 \\
\hline 5 & $\begin{array}{l}\text { Lifetime < 1 year, No service, Non Chargeable, } \\
\text { Difficult to use, indicators are not clear }\end{array}$ & 1 \\
\hline
\end{tabular}

g. Source: primary and secondary data

After specify the CSF's and describe Relative Positioning based on data collection, the next step is conducting in-depth analysis. In-depth analysis should be observing 2 important things:

- Competitors:

- Existing competitors

- New competitors

- Non Competitors

Competitor Intelligence and New Competitive Advantage Analysis

CI analysis conducted by mapping CSF's analysis and relative positioning for all products. The CI analysis of product $\mathrm{X}$ LIPI with 3 competitors shown in figure below:

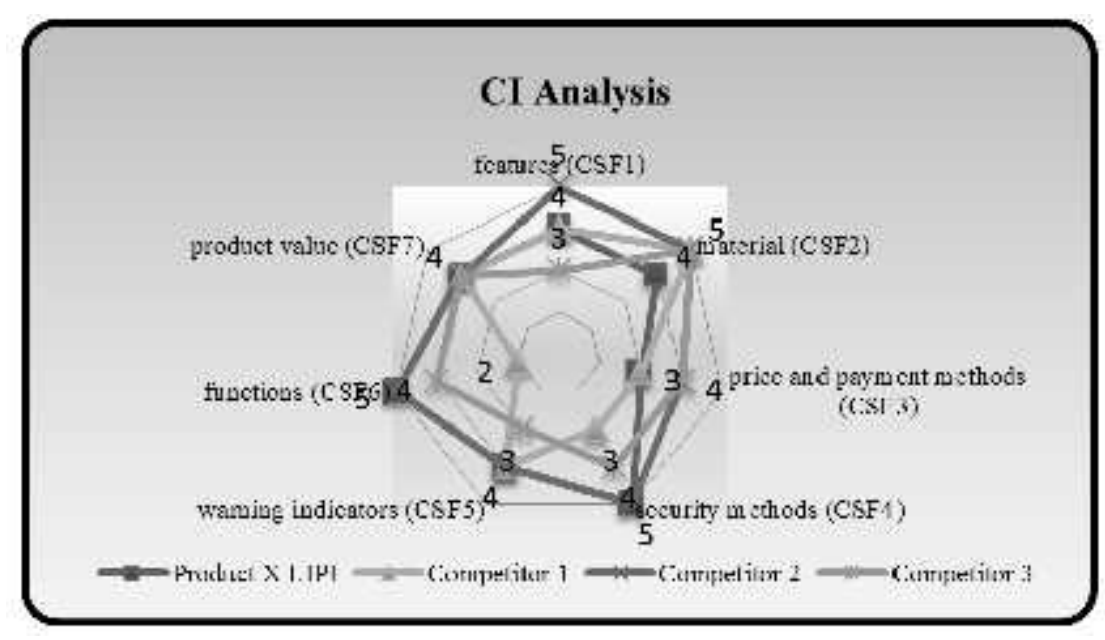

Fig. 4. The results of the mapping product X LIPI with competitors

From Fig. 4. the positioning product $\mathrm{X}$ is not having many different with the competitors. If the product X LIPI released in the market, it will make the product X LIPI has no strength and could be make the product X LIPI failure in the market. The position of product X LIPI shown in this figure below: 


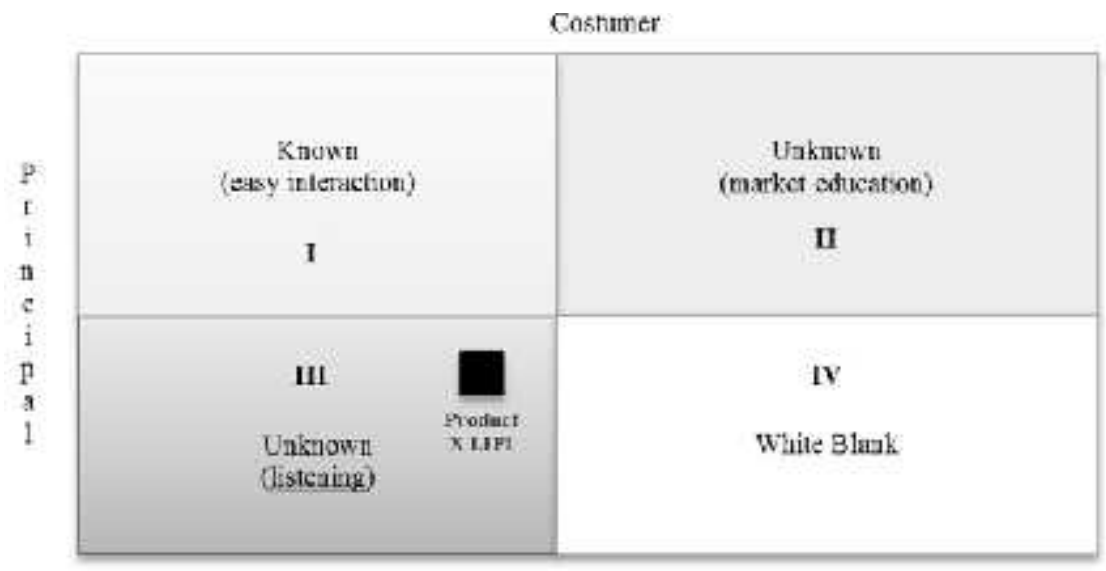

Fig. 5. Position of Product X LIPI (In-depth analysis result)

To improve competitiveness of product $\mathrm{X}$ LIPI, implementation of strategy product development needed. One of strategy business can be performed with analyses the other CSF's. To get the new CSF's can be founded in CSF's non competitors. But to be considered, CSF's can be added if the non-competitors has same field with product X LIPI. For this CSF's non competitors can be taken from security system warning for other products in same field.

In-depth analysis for CSF's non competitors has requirement where CSF's in non-competitors should be has a new criteria and not yet owned by the other competitors. Beside that CSF's non competitors should be also pay attention to the wishes of the customers. Good CSF's analysis considers the quality of product by demand of market (costumers) and the position of its product with the other competitors. Do not let a competitor intelligence process reaches a process called "wide spread obsession". Wide spread obsession is a pattern or behaviour that too much attention to competitors and ignore the wishes of the customers.

In this analysis for CSF, s non competitors taken 2 products those has similar global field. CSF's analysis also performed for these non-competitors product.

The CSF's non competitors are:

\section{- System (CSF8)}

- Integration module (CSF9)

CSF 8 obtaining by observed alarm warning system which the product is not have a same function, but still have in same field as an alarm warning system. CSF 9 obtaining by observed the product to make Product X LIPI has integrated system for powerful function and response. Relative positioning for these CSF's shown in table below:
TABLE VIII. RELATIVE POSITIONING FOR CSF8 NON COMPETITORS

\begin{tabular}{|l|l|l|}
\hline No & \multicolumn{1}{|c|}{ Criteria } & Grade \\
\hline 1 & $\begin{array}{l}\text { More than 1 sensor, range detector: far (range } \geq 1 \\
\text { meter), simple }\end{array}$ & 5 \\
\hline 2 & $\begin{array}{l}\text { More than 1 sensor, range detector: far ( range } \geq 1 \\
\text { meter), complicated }\end{array}$ & 4 \\
\hline 3 & $\begin{array}{l}\text { More than 1 sensor, range detector: near (range < 1 } \\
\text { meter), complicated }\end{array}$ & 3 \\
\hline 4 & $\begin{array}{l}\text { More than 1 sensor, range detector: near (range < 1 } \\
\text { meter), complicated }\end{array}$ & 2 \\
\hline 5 & $\begin{array}{l}\text { Just have 1 sensor, range detector: near (range < 1 } \\
\text { meter), complicated (1) }\end{array}$ & 1 \\
\hline
\end{tabular}

TABLE IX. RELATIVE POSITIONING FOR CSF9 NON COMPETITORS

\begin{tabular}{|l|l|l|}
\hline No & \multicolumn{1}{|c|}{ Criteria } & Grade \\
\hline 1 & $\begin{array}{l}\text { Integrated sensor system, automatic, electronic and } \\
\text { mechanic integration }\end{array}$ & 5 \\
\hline 2 & Integrated sensor system, manual, mechanic system & 4 \\
\hline 3 & Integrated sensor system, automatic, electronic system & 3 \\
\hline 4 & Sensor system not integrated, manual, electronic system & 2 \\
\hline 5 & Sensor system not integrated, manual, mechanic system & 1 \\
\hline
\end{tabular}

${ }^{\text {i. }}$ Source: primary and secondary data

From the CSF 8 and CSF 9 can be added to product X LIPI as new added value. Adding these new values will make the product X LIPI has better performance than other competitors. Although product X LIPI is more expensive than others (shown in Fig. 4.), but with the new value will make the product $X$ LIPI has more competitiveness in the market. Process to adding new value can be achieved with reverse engineering and also market education so that product X LIPI has more chance to compete in the market. The CI analysis result after performed in-depth analysis for CSF 8 and CSF 9 shown in figure below: 


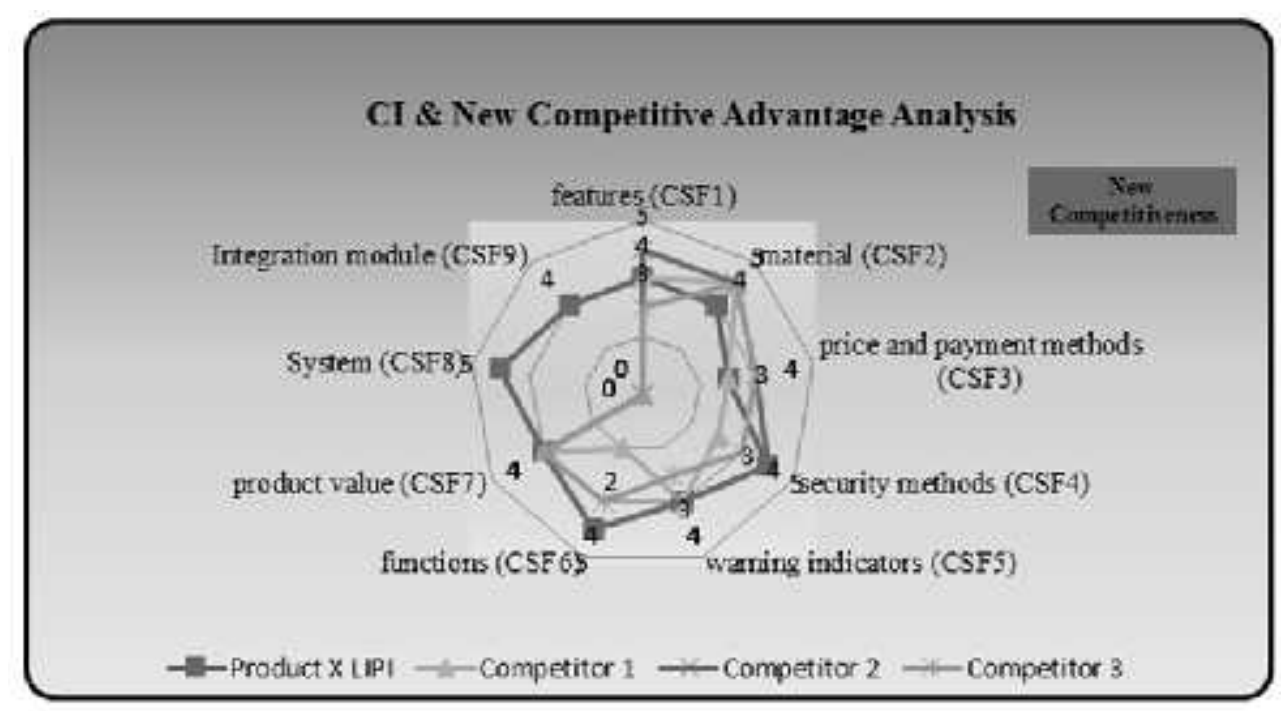

Fig. 6. New Added value for strategy business development product X LIPI

In developing those new values, it is very important to consider many aspects such as budgeting, human resources and also strategy to use all CSF's or not. In some case, using all CSF's can make the best result, but some others the business manager can take a key decision to not use some CSF's after looking the market acceptance. And also the new CSF can be used as competitive benchmark of the product [14]. The position product $X$ LIPI after has new values (new competitive) shown in figure below:

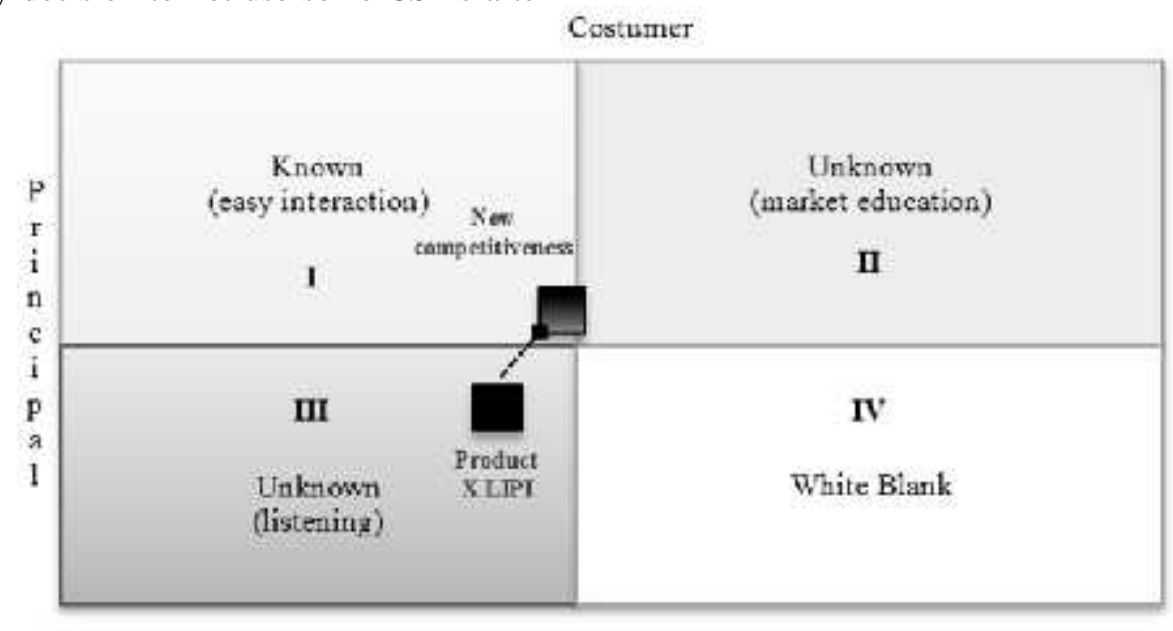

Fig. 7. Position of Product X LIPI after added new competitiveness (new added value)

Fig. 7. shown the improvement of product X LIPI to make the product can be accepted in the market. Product X LIPI moving from quadrant III where that quadrant means the product should be "listening" the market and see what the market need. After conducted CI analysis and in-depth analysis for all CSF's which are would be considered influential for strength of product, the position now in quadrant I-III. These quadrants mean that the product $X$ LIPI still should be improving the strategy marketing with market education. And also with the position product X LIPI in quadrant I will make the product can be easily interaction with consumer because with adding new values based on costumer will make the product more acceptable in the market.

\section{Counter Intelligence}

Counter-intelligence can be defined as intelligence gathered about an adversary's intelligence activities and capabilities to unmask and inhibit adversarial intelligence operations and capabilities [15]. Counter-intelligence is one of the strategy business the keep the key strategy issues business save and to enhance competitiveness.

One way to counter intelligence can be using IP protection. The formal definition, according to the World Intellectual Property Organization, IP is creations of the mind inventions, literary and artistic works, symbols, names, images, and designs used in commerce [16]. Intellectual property (IP) can be anything from a particular manufacturing process to 
plans for a product launch, a trade secret like a chemical formula, trademark, copyright, patents or industrial design of product.

In this case, Product X LIPI protected by using patent for the system, process, industrial design, and also the integrated system that existed in this product. Nevertheless, IP protection also can improve the value of the product, because with the IP right the product can be easily penetrating the market and prevent the competitors to imitate the new competitiveness of the product. WIPO also mention that the IP protection is very crucial for marketing the products because the following reason below [17]:

- Differentiating your products and services and making them easily recognizable

- Promoting your products or services and creating a loyal clientele

- Diversifying your market strategy to various target groups

- Marketing your products or services in foreign countries

From the explanation above, the best strategy to build well competitor intelligence is protect the new added values those achieved from the analysis and then protecting these values using IP protection or other strategy protection.

\section{CONCLUSION}

Competitor intelligence is one of many tools in business development to create new strategy for development product so that the product can be competing in the market. Form CI analysis for product X LIPI shows that 7 CSF's that previously identified should be add 2 new CSF's as new added value. Adding 2 new CSF's for product X LIPI are the new strategy business to make the product more competitiveness in the market.

\section{REFERENCES}

[1] Xia B.S. and Gong P. Review of business intelligence through data analysis. Benchmarking: An International Journal. 21, 2014, p300 311.

[2] LI-SHENG. A. K, "Sun Tzu's War Theory in The Twenty First CenturyStrategy Research Project", U.S. Army War College,Carlisle Barracks,Carlisle,PA, 17013-5050, 2007.

[3] Kotler, P. \& Keller, K. "Marketing Management 12th Edition", Upper Saddle River, New Jersey 07458, Prentice Hall, 2006.

[4] Wright, S., Eid, E.R. \& Fleisher, C.S., Competitive intelligence in practice: Empirical evidence from the UK retail banking sector. Journal of Marketing Management, 25(9/10):941-964, 2009

[5] Nasri, W., Competitive intelligence in Tunisian companies. Journal of Enterprise Information Management, 24(1), 2010, p53-67.

[6] Johns, P. and Van Doren, D.C., Competitive intelligence in service marketing: A new approach with practical application. Marketing Intelligence \& Planning, 28(5), 2010, p551-570.

[7] Keller S \& Aiken C, "The Inconvenient Truth about Change Management", Mckinsey Quarterly, April, 2009

[8] Rifai, George, Guidebook Workshop Competitors Intelligence-Finding, Analyzing, and Using Information about Competitor to Gain Competitive Advantage, 2011

[9] Rockart, John F., Chief Executives Define Their Own Data Needs. Harvard Business Review, 1979

[10] Caralli, Richard A., The Critical Success Factor Method: Establishing a Foundation for Enterprise Security Management. (CMU/SEI-2004-TR010), 2004

[11] The Society of Management Accountants of Canada - Monitoring Customer Value., Hamilton, 1995

[12] Regulation Ministry of Industry Republic Indonesia No 16/MIND/PER/2/2011

[13] Karlsson, Charlie and Picard, Robert G.,Media Clusters: Spatial Agglomeration and Content Capabilitie. Cheltenham: Edward Elgar Publishing, 2011

[14] E\&S Tucson - November 1999, Benchmarking from A to Z Benchmarking from A to Z Kay Kendall Director, Quality and Six Sigma Using Benchmarking to Achieve Improved Process. 1999

[15] Odom, William E., Fixing Intelligence, New Haven / London, Yale University Press., 2003

[16] http://www.wipo.int/about-ip/en/

[17] http://www.wipo.int/sme/en/ip_business/marketing/marketing.htm 